\title{
Feeding practice in acute stroke patients in a tertiary care hospital
}

\author{
Md. Titu Miah, Mohammad Al-Amin, Mohammad Ashik Imran Khan, KFM Ayaz, \\ MH Zakaria, Srijoni Ahmed, HAM Nazmul Ahasan \\ Department of Medicine, Dhaka Medical College Hospital, Dhaka \\ Email:ashikmrn@yahoo.com
}

\begin{abstract}
Background: Feeding is a basic component of care and it is the most common and difficult management issue for stroke patients. Objective of this study was to know the practice of feeding (oral $\&$ nasogastric tube feeding), different types of food used and their caloric value in stroke patients. Materials \& Methods: This direct observational study was done from June 2010 to November 2010, in different medicine wards of Dhaka Medical College Hospital, and included 100 acute stroke patients confirmed by CT scan or MRI of brain and duration of hospital stay for at least 24 hours. Results: Out of 100 cases, $22 \%$ took their feeding orally and $78 \%$ cases through nasogastric tube. Artificial milk powder $66 \%$ cases (NG tube vs. Orally, $58 \%$ vs. $8 \%$ ), juice $18 \%$ (NG tube $13 \%$ vs. orally $5 \%$ ), horlicks \& juice \& soup $10 \%$ (NG tube vs. Orally, $7 \%$ vs. $3 \%$ ), khichury $2 \%$ orally, bread \& egg \& shuji $4 \%$ cases orally. In 100 cases studied, none of them fulfilled the calorie requirement up to the standard level according to the guideline of Nutrition \& Food Science Institute, of Dhaka University, Bangladesh. Conclusion: Though this study was small scale but the magnitude of under nutrition among stroke patients revealed is alarming and needs urgent attention.
\end{abstract}

\section{Introduction}

Stroke is a common medical emergency with an annual incidence of between 180 and 300 per 100000 and in many developing countries the incidence is rising due to less healthy life styles ${ }^{1}$. Undernutrition is a common problem and is poorly recognized in hospital setting. It has been seen that $1 / 3$ of patients are affected by moderate or severe malnutrition on admission and elderly are particularly at greater risk $^{2}$. Underlying causes leading to poor nutritional intake are many which includes reduced conscious level, an unsafe swallow, arm or facial weakness, poor mobility and ill fitting dentures. Malnutrition in acute stroke is associated with increased prevalence of complication, impaired immunologic function and a higher mortality rate ${ }^{3-5}$. Appropriate nutritional support reduces complications and mortality in stroke patients ${ }^{6}$. stroke patients make up a major bulk of admission in most tertiary hospitals. In our centre alone, a total of almost 4000 patients were admitted with stroke which made up to $14 \%$ of total admitted patients in medicine in 20097. But unfortunately still today, nutritional aspect of stroke patients is a neglected field in Bangladesh. This study was conducted to find out the feeding practice in acute stroke patients in a tertiary hospital to have a peek into the actual scenario.

\section{Materials \& Methods}

This direct observational study was carried out in randomly selected 100 acute stroke patients from June 2010 to November 2010 in different medicine wards of Dhaka Medical College Hospital and included those patients who gave informed written consent \& stayed in hospital for at least 24 hours. Stroke was confirmed by CT scan or MRI of brain. All data were recorded in pre formed data sheet. The calorie value of different food items were calculated according to the guideline of Nutrition \& Food Science Institute, Dhaka University, Bangladesh.

Calorie value of some foods (Nutrition \& Food Science Institute, Dhaka University)

\begin{tabular}{lc}
\hline Name of food $(100 \mathrm{gm})$ & Calorie value $(\mathrm{kcal})$ \\
\hline Milk powder & 496 \\
Shuji & 348 \\
Rice & 365 \\
Coarse flour & 341 \\
Lentil & 343 \\
Egg & 177 \\
Potato & 97 \\
Mustard oil & 900 \\
Vegetable & 43 \\
Barley & 336 \\
Chicken & 109 \\
Mustard oil & 900 \\
Artificial Juice & 48 \\
\hline
\end{tabular}




\section{Results}

Out of 100 cases, $78 \%$ took feeding with nasogastric tube and $22 \%$ orally. They took different items of food which were, artificial milk powder $66 \%$, juice $18 \%$, horlicks \& juice \& soup $10 \%$, others were $6 \%$ cases (bread, egg, shuji, khichury) (Table-I). Most of the cases did not fulfill the calorie requirement upto the standard level according to the guideline of Nutrition and Food Science Institute, Dhaka University, Bangladesh shown in table-II and table-III.

Table I is showing Different patterns of feeding practice and types of food used among stroke patients where majority were fed by nasogastric tube $(78 \%)$ and most patient using artificial milk powder $(58 \%)$.

Table I: Pattern of feeding \& different items of food used $(n=100)$

\begin{tabular}{lcc}
\hline Items of food & $\begin{array}{c}\text { Nasogastric } \\
\text { tube (78\%) }\end{array}$ & Orally (22\%) \\
\hline Artificial milk Powder & 58 & 8 \\
Artificial juice & 13 & 5 \\
Horlicks $^{1} \&$ juice \& Soup(chicken) & 7 & 3 \\
Bread \& egg \& shuj $^{2}$ & 0 & 4 \\
Khichury $^{3}$ & 0 & 2 \\
\hline
\end{tabular}

1. Horlicks - Malted Barley, Wheat Flour, Sugar, Milk

2. Shuji - Rice based diet

3. Khichury - Rice, Lentils, Mustard Oil

Table II is showing different pattern of feeding practice in stroke patients.

Table II: Different practice of feeding

\begin{tabular}{llcccc}
\hline $\begin{array}{l}\text { Pattern of } \\
\text { Feeding }\end{array}$ & $\begin{array}{c}\text { Food } \\
\text { Items }\end{array}$ & $\begin{array}{c}\text { No. of } \\
\text { cases }\end{array}$ & $\begin{array}{c}\text { No of } \\
\text { T.S.F }\end{array}$ & Water (Avg.) & $\begin{array}{c}\text { Times/ } \\
\text { day }\end{array}$ \\
\hline \multirow{2}{*}{$\begin{array}{l}\text { Nasogastric } \\
\text { Tube }\end{array}$} & Milk & 8 & 6 & $200 \mathrm{ml}$ & 10 \\
& powder & 50 & 4 & $150 \mathrm{ml}$ & 5 \\
& Juice & 13 & - & $100 \mathrm{ml}$ & 4 \\
& Horlicks & 7 & - & $100 \mathrm{ml}$ & 2 \\
& Juice & 7 & - & $100 \mathrm{ml}$ & 4 \\
Orally & Soup & 7 & - & $100 \mathrm{ml}$ & 2 \\
& & & & & \\
& Milk & & & & 4 \\
& Powder & 8 & 3 & $100 \mathrm{ml}$ & 4 \\
& Juice & 5 & - & $150 \mathrm{ml}$ & 5 \\
& Horlicks & 3 & 3 & $100 \mathrm{ml}$ & 3 \\
& Juice & 3 & - & $100 \mathrm{ml}$ & 5 \\
& Soup & 3 & - & $100 \mathrm{ml}$ & 2 \\
& Khichury & 2 & - & $150 \mathrm{ml}$ & 2 \\
& Bread & 4 & - & $2 \mathrm{piece}$ & 2 \\
& Egg & 4 & - & $1 \mathrm{piece}$ & 2 \\
& Suji & 4 & - & $150 \mathrm{ml}$ & 2 \\
\hline
\end{tabular}

Table III Showing gross discrepancy between actual requirement and calorie provided to the patients of stroke patients. Here stanadard requirement is around $2000 \mathrm{k} / \mathrm{cal} / \mathrm{d}$.
Table III: Discrepancy between actual demand and consumption in respect of calorie value

\begin{tabular}{lccc}
\hline Feeding Pattern & Type of Food & $\begin{array}{c}\text { Calorie consumed } \\
\text { (Appx.) }\end{array}$ & $\begin{array}{c}\text { Calorie } \\
\text { deficit(Appx.) }\end{array}$ \\
\hline Nasogastric feeding & 852 & 1148 \\
Milk & 191 & 808 \\
Juice & 1083 & 917 \\
Orally & Horlicks \& Juice \& Soup & & \\
& & 133.32 & 1866.68 \\
& Milk & 350 & 1650 \\
Juice & 1237.5 & 762.5 \\
\multicolumn{2}{c}{ Horlicks \& Juice \& soup } & 966 & 1034 \\
Khichury & 754.5 & 1245.5 \\
\hline \multicolumn{2}{c}{ Bread \& Egg \& Shuji } &
\end{tabular}

Table IV showing causes underlying the inadequate replacement where most attendants pointing lack of food suitable for stroke patients $(90 \%)$ as the cause.

Table IV: Underlying cause of inadequate calorie replacement

\begin{tabular}{lc}
\hline Cause of undernutrition & Percentage \\
\hline Lack of availability of diet & $90 \%$ \\
Party Ignorance & $70 \%$ \\
Poverty & $70 \%$ \\
Poor Instruction by doctors & $50 \%$ \\
\hline
\end{tabular}

\section{Discussion}

Feeding is the most common and difficult management issue for stroke patients. Davalos and colleagues in Spain showed that patients with stroke have a greater stress response (based on serum cortisol level) than those with milder stroke and associated with deterioration in nutritional status. In this study, 54 cases were totally unconscious and took feeding through nasogastric tube. Another 24 cases out of remaining 46 cases took feeding through nasogastric tube due to inability to swallow completely despite being conscious. Remaining 22 cases took feed orally with low amount. Up to $50 \%$ patients are unable to swallow safely due to stroke. In most studies, deterioration in nutrition occurred more often in dysphagic patients or in those who need help with feeding $^{9-12}$. Patients who are capable of swallowing liquids and food may have a poor appetite because of the effects of intercurrent illness or medication and they may eat more slowly or be less keen to eat because of facial weakness, lack of dentures or poor arm function ${ }^{13}$. In our study we found that a majority of our subjects were receiving nasogastric feeding (78\%) (Table I).

About a fifth of patients with acute stroke are malnourished on admission to hospital ${ }^{14}$. Stroke patients with poor nutritional status may worsen during hospital admission as well ${ }^{8,11,12,15,16}$. It has been related to eating problems, age, poor nutritional status on admission and immobilization in patients with impaired functional capacity ${ }^{12,17}$. 
Acute stroke must be considered moderately hypercatabolic and since catabolic disease alters body composition rapidly, gradual shrinkage of body fat and body cell mass compartment occurs ${ }^{18}$. It modifies the metabolism of carbohydrate and every aspect of the immune system is damaged by inadequate nutrition and stress reaction ${ }^{6,19}$.

Some clinicians prefer to introduce tube feeding very soon after the stroke, others delay for day's and sometimes weeks. One randomised trial has suggested that oral supplementation after stroke improves nutritional parameters ${ }^{20}$. Early enteral nutrition after stroke reduced length of stay in hospital $^{21}$. Dysphagia may lead to aspiration pneumonia and swallowing problems may contribute to poor outcome independently of other markers of overall stroke severity and initial coma $^{10,22}$. In our study, out of 100 patients, 78 patients were on tube feeding possibly as our centre was a tertiary level hospital and deals mostly with difficult patients dealing with mostly difficult cases.

The striking finding of this study was that though most patients were receiving some form of diet following stroke but analysis of the nutritional value of the foods consumed showed that none were not up to the standard mark. In this study, most of the patients took artificial milk powder and juice for their calorie requirement (Table I) which was inadequate in amount and did not fill the standard level of requirement of calorie per day according to the guideline of Food and Nutrition science department of Dhaka University, Bangladesh. When calculating dietary needs, protein requirement is put as the first priority, then splitting the remaining calories between fat and carbohydrate. Eating a well balanced diet with an emphasis on fresh vegetables and fruits; lean, clean protein foods; and whole grain is necessary in the recovery process from stroke. $2000 \mathrm{kcal} /$ day and 2.5 to $3 \mathrm{l} /$ day fluid is necessary in an adult to meet basal needs ${ }^{23-25}$. But in our study, all of our study subjects were receiving diets with calorie value way below the standard level (Table-III). Under replacement of calorie was present in patients in both nasogastric feeding and on oral feeding as well. Fluid requirements were also not met leading to potential risk of dehydration in these patients as well. Long term consequence of this under nutrition will surely affect the long term functional outcome of these patients. But unfortunately due to the limited nature of this study, such outcomes could not be evaluated. When inquired, most of the care givers attributed the cause of under replacement of calorie to lack of availability of special diet specifically designed for stroke patients $(90 \%)$ in the hospital (Table-IV). Ignorance of the caregivers
(70\%), poverty (70\%), and poor instruction by the doctors $(50 \%)$ was also other causes (Table-IV). In this study we did not measure the nutritional status and any complication for malnutrition due unavailability of nutritionist and also due to the nature of the study.

\section{Conclusion}

This is very small hospital based study considering the disease burden. Its importance cannot be underestimated. It should be mandatory to evaluate the nutritional status of stroke patients appropriately and supply the well balanced diet for early recovery and reduce the burden on family, society and the economy of the country.

\section{References}

1. Allen CMC, Lucek CJ, Dennis M. Neurological disease. In: Boon NA, Colledge NR, Walken BR, Hunter JA, eds. Davidson's Principles and Practice of Medicine, $21^{\text {st }}$ ed. London, Churchill Livingstone Elsevier; 2010: 1180-1191.

2. Harlon P, Byers M, Walker BR, Macdonald HM. Eds. Environmental and nutritional factors in disease. In: Boon NA, Colledge NR, Walker BR, Hunter JA, eds. Davidson's Principles and Practice of Medicine, $21^{\text {st }}$ ed. London, Churchill Livingstone Elsevier; 2010: 123.

3. Albiin N, Asplund K, Bjermer L. Nutritional status of medical patients on emergency admission to hospital. Acta Med Scand 1982; 212: 151-156.

4. Reilly JJ, Hull SF, Albert N, et al. Economic impact of malnutrition: a model system for hospitalized patients. JPEN J Parenter Enteral Nutr 1988; 12: 371-376.

5. Dominioni L, Dionigi R. Immunological function and nutritional assessment. J Parenter Enteral Nutr 1987; 11: 70-72.

6. Cabre E, Gonzalez- Huix F, Abad-Lacruz A, et al. Effect of total enteral nutrition in the short term outcome of several malnourished cirrhotics: a randomized controlled trial. Gastroenterology 1990; 98: 715-720.

7. Department of Medicine, Dhaka Medical College Hospital. Annual Report 2009, Dhaka, Bangladesh 2009: 24-26

8. Davalos A, Ricart W, Gonzalez-Huix F, et al. Effect of malnutrition after acute stroke on clinical outcome. Stroke 1996, 27: 1028-32.

9. Smithard DG, O'Neill PA, Park C, et al. Complication and outcome after acute stroke. Does dysphagia matter? Stroke 1996; 27: 1200-4.

10. Gordon C, Langton Hewer R, Wade DT. Dysphagia in acute stroke. BMJ 1987; 295: 411-414.

11. Barer DH. The natural history and functional consequences of dysphagia after hemispheric stroke. J Neurol Neurosurg Psychiatry 1989; 52: 236-41. 
12. Onosson $\mathrm{M}$, Ek AC, Bjurulf $\mathrm{P}$, et al. Feeding dependence and nutritional status after acute stroke. Stroke 1994; 25: 366-71.

13. Carr EK, Hawthorn PJ. Lip function and eating after a stroke: a nursing perspective. J Adv Nurs 1988; 13 : 447-51.

14. Dennis M. Nutrition after stroke. Br Med Bull 2000; 56(2):466-475.

15. Axelsson K, Asplund K, Norberg A, Alafuzoff I. Nutritional status in patients with acute stroke. Acta Med Scand 1988; 224:217-24.

16. Gariballa SE, Parker SG, Taub N, Castleden CM. Influence of nutritional status on clinical outcome after stroke. Am J Clin Nutr 1998; 68: 275-81

17. Axelsson K, Asplund K, Norberg A, Eriksson S. Eating problems and nutritional status during hospital stay of patients with severe stroke. J Am Diet Assoc 1989; 89: 1092-1096.

18. Clutter WE, Bier DM, Shah SD, Cryer PE. Epinephrine plasma metabolic clearance rates and physiologic thresholds for metabolic and hemodynamic actions in man. J Clin Invest 1980; 66: 94-101.

19. Munck A, Guyre PM, Holbrook NI. Physiological functions of glucocorticoid in stress and their relationship to pharmacological actions. Endocr Rev 1984; 5: 25-44.

20. Gariballa SE, Parker SG, Castleden CM. A randomised controlled trial of nutritional supplementation after stroke. Age Ageing 1998; 27(1): 66.

21. Nyswonger GD, Helmchen RH. Early enteral nutrition and length of stay in stroke patients. J Neurosci Nurs 1992; 24: 220-3.

22. Holas MA, DePippo KL, Reding MJ. Aspiration and relative risk of medical complications following stroke. Arch Neurol 1994; 51: 1051-1053.

23. Alternative and Complementary Medicine for Stroke. Source http://www.holisticonline.com/remedies/Heart/ stroke. [Accessed on $15^{\text {th }}$ November 2010].

24. Ganong WF. Energy balance, Metabolism \& Nutrition. In: Review of Medical Physiology. $21^{\text {st }}$ ed. New York: McGraw-Hill; 2003: 311.

25. Field MJ, Burnett L, Sullivan DR, Stewart P. Clinical biochemistry and metabolism. In: Boon NA, Colledge NR, Walker BR, Hunter JA, eds. Davidson's Principles and Practice of Medicine, $20^{\text {th }}$ ed. London. Churchill Livingstone Elsevier; 2010:431. 